\title{
SPESSARTITE IN THE CAMBRIAN MANGANESE ORE OF MERIONETHSHIRE.
}

Sir,-Hitherto, all available published accounts of the Manganese deposits, which occur interstratified in the Cambrian Harlech Grit Series of Merionethshire, have referred to the ore in its unaltered condition as consisting of a mixture of silicate and carbonate of manganese. ${ }^{1}$ Professor A. H. Cox and Dr. A. K. Wells state that it consists of alternations of dialogite (manganese carbonate) and rhodonite (pink manganese silicate). ${ }^{2}$

During the course of research which is now proceeding under the direction of Prof. H. P. Lewis, petrographical work, in conjunction with chemical analysis, has shown that the silicate constituent in the ore is largely, if not exclusively, in the form of very minute crystals of garnet. These are of pale yellow colour and the mineral conforms closely in composition to that of pure spessartite.

Austin W. Woodland.

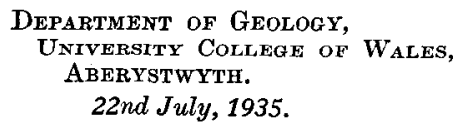

1 Dewey, H., and Dines, H. G., Mem. Geol. Survey, Special Reports on the Mineral Resources of Great Britain, vol. i, Tungsten and Manganese Ores ;
3rd edit., 1923, p. 63 .

${ }^{2}$ Geology of the Dolgelley District, Merionethshire, Proc. Geol. Assoc., vol. xxxviii, 1927, p. 270. 